\title{
Biometric variability of goat populations revealed by means of principal component analysis
}

Luanna Chácara Pires ${ }^{1}$, Théa M. Medeiros Machado², Adriana Mello Araújo ${ }^{3}$, Timothy A. Olson ${ }^{4}$, João Batista Lopes da Silva ${ }^{5}$, Robledo Almeida Torres ${ }^{2}$ and Márcio da Silva Costa ${ }^{6}$

${ }^{1}$ Departamento de Agronomia, Universidade Federal de Piauí, Bom Jesus, PI, Brazil.

${ }^{2}$ Departamento de Zootecnia, Universidade Federal de Viçosa, Viçosa, MG, Brazil.

${ }^{3}$ Empresa Brasileira de Pesquisa Agropecuária, Embrapa Meio Norte, Teresina, PI, Brazil.

${ }^{4}$ Department of Animal Science, University of Florida, Gainesville, FL, USA.

${ }^{5}$ Departamento de Engenharia de Agricultura, Universidade Federal de Viçosa, Viçosa, MG, Brazil.

${ }^{6}$ Departamento de Ciência Animal, Universidade Federal de Piaui, Teresina, PI, Brazil.

\begin{abstract}
The aim was to analyze variation in 12 Brazilian and Moroccan goat populations, and, through principal component analysis (PCA), check the importance of body measures and their indices as a means of distinguishing among individuals and populations. The biometric measurements were wither height $(\mathrm{WH})$, brisket height $(\mathrm{BH})$ and ear length (EL). Thorax depth (WH-BH) and the three indices, TD/WH, EL/TD and EL/WH, were also calculated. Of the seven components extracted, the first three principal components were sufficient to explain $99.5 \%$ of the total variance of the data. Graphical dispersion by genetic groups revealed that European dairy breeds clustered together. The Moroccan breeds were separated into two groups, one comprising the Drâa and the other the Zagora and Rhâali breeds. Whereas, on the one side, the Anglo-Nubian and undefined breeds were the closest to one another the goats of the Azul were observed to have the highest variation of all the breeds. The Anglo-Nubian and Boer breeds were similar to each other. The Nambi-type goats remained distinct from all the other populations. In general, the use of graphical representation of PCA values allowed to distinguish genetic groups.
\end{abstract}

Keywords: biometrics, genetic resources, goat breeds, morphometrics, population characterization.

Received: March 14, 2012; Accepted: May 29, 2012.

\section{Introduction}

Geographic isolation over time, along with small population size and the consequences of natural and artificial selection in domesticated animals, have contributed to the appearance of a large variety of genetic types within species, sometimes called breeds. These same factors have also contributed to variation within the breeds themselves (Hall and Bradley, 1995; Bruford et al., 2003).

The standard procedure used in Brazil for defining a goat breed is first there cognition of a standard population phenotype by the Ministry of Agriculture, followed by its registration with the Goat Genealogical Registration Service (Brasil, 1977). This definition of breed, a group of animals with standardized qualitative characteristics, was developed in England during the eighteenth century (Audiot, 1985; Sierra Alfranca, 2001).

Farm animals of colonial Brazil originally came from Portugal and the Cape Verde islands, and later from Spain.

Send correspondence to Luanna Chácara Pires. Departamento de Agronomia, Universidade Federal de Piauí, BR 135, km 3, 64900-000 Bom Jesus, PI, Brazil. E-mail: Iualu66@yahoo.com.br.
Sahelian goats from the Western Sahara and their crosses entered Brazil by way of the Cape Verde Islands, where they had been previously introduced by the Portuguese. The Portuguese had acquired Arabian, Persian (Iran) and Maghrebian (Morocco, Algeria and Tunisia) horses, before Brazil was discovered and later were thought to have introduced their descendants into Brazil. An ancient North African influence is also generally assumed regarding the origin of asinine, equine and ovine animals of the Iberian Peninsula (Machado TMM, 1995, PhD thesis, University of Paris XI, Paris). Andrade (1982) stated that the introduction of goats and other livestock species to Brazil coincided with the arrival of the first African slaves.

At the beginning of the nineteenth century, goat breeds selected for improving production began to arrive in Brazil. The European breeds, Alpine, Saanen and Toggenburg, were selected for increasing milk production and the Anglo-Nubian for both milk and meat. The Anglo-Nubian breed was formed in England by crossing African long-drooping-eared goats from the Nile and common English goats (Mason, 1988). The Boer breed, developed by South African farmers of the eastern Cape, came about 
by crossing indigenous Hottentot and Bantu animals with imported Nubian and Indian goats (Skinner, 1972; Erasmus, 2000; Malan, 2000).

Most Brazilian goats do not have a standardized phenotype, and thus, are classified as of an undefined breed (UDB). Not with standing, some goats that were introduced into northwestern Brazil in the distant past have acquired peculiar phenotypic characteristics, e.g. the Marota goat is a white-coated ecotype. The Azul ecotype designates roan-coated goats with a fawn pigment pattern, thereby assuming a gray or "Azul" appearance (Machado TMM, 1995, PhD thesis, University of Paris XI, Paris). The Nambi goat's distinguishing characteristic is its tiny ears.

Among the Moroccan goat populations, only the Drâa have well-defined phenotypic characteristics and production (milk and meat) information (Hossaini-Hilari and Benlamlih, 1995; Hossaini-Hilari and Mouslish, 2002). On comparing French and Moroccan goats using INRA microsatellite markers and $\alpha$-casein polymorphism, it was noted that the Drâa-Zagora sample clustered with the Rhâali, separate from the French goats; among which, goats from the Pyrenees formed a separate stem from the Saanen, Alpine and Poitevine (Ouali et al., 2002).

The physical measurements were taken based in the knowledge that considerable variation exists among the various groups, from long-legged to midget goats and from goats with long, droopy ears to those with short, erect ears (Epstein, 1971; Mason, 1988).

Over the past two decades, improvements in phenotype marker methodology have facilitated the simultaneous measurement of many characteristics (Lauvergne, 1988; Rodero et al., 1992; Jordana et al., 1993; Herrera et al., 1996; Jordana and Parés, 1999; Bedotti et al., 2004; Dossa et al., 2007; Rocha et al., 2007; Chácon et al., 2011), the establishment of indices between two body measurements (Bourzat et al., 1993; Bouchel et al., 1997; Lauvergne et al., 2000), and the integration of genetics statistics and informatics solver the last two decades. Subsequently, phenotypic and molecular markers began to be analyzed jointly using multivariate analyses. Breeds have acquired a quantitative measure for uniformity among their individuals (reduced intra-population variability) and become different from individuals of other breeds (variability amongst populations). The biological importance of biometric measures submitted to multivariate analyses is the observation of clustering of some individuals, and the distance between them and those of other populations. Those individuals clustered together (i.e. similar for phenotypic measures) could be recognized as an official breed.

Phenetic distances establish relations of similarity among populations with the purpose of classification, studied on the genetic and evolutionary distances (Meyer, 1996).

Principal component analysis (PCA) consists of transforming a set of variables $Z_{1}, Z_{2}, \ldots, Z_{p}$ into a new set of uncorrelated variables $\mathrm{Y}_{1}\left(C P_{1}\right), \mathrm{Y} 2\left(C P_{2}\right), \ldots, \mathrm{Y}_{\mathrm{p}}\left(C P_{P}\right)$ that are arranged in descending order of variance (Liberato et al., 1999). Each principal component is a linear combination of all the original variables, independent of each other, and estimated, with the aim of retaining the maximum of information and total variation contained in the original data. The main i.e. of this procedure, however, is that a few of the first principal components contain most of the variability of the original data. PCA can also unveil relationships not previously identified, contributing for a better interpretation of the collected data (Baker et al., 1988).

The aim of this study was to verify the ability of body measurements and their indices using PCA to discriminate among individuals and populations.

\section{Material and Methods}

Obtained data were of 796 Brazilian and Moroccan female goats, all over two-years-old. Additional data, collected between 1995 and 2008, included information on phenotype and ownership of each animal sampled.

Exotic breeds were sampled (34 Toggenburg, 86 Saanen, 28 Anglo-Nubian, 78 Alpine and 26 Boer) in Brazil (Minas Gerais State and in the Federal District). In addition, in the State of Piauí, 29 heads of the Azul type, 32 of Marota type, 35 of Nambi type and 123 goats lacking defined breed characteristics (UDB) were measured. The exotic breed goats sampled in Brazil, the Alpine, Saanen, Toggenburg, Anglo-Nubian and Boer, are registered in their respective Brazilian herdbooks. The local Brazilian goats, Azul, Marota, Nambi and UDB lack herdbook information.

In Morocco, the sample comprised 102 local Drâa goats from the Center for Goat Research in the village of Sidi Flah, in Skoura. A further 34 Zagora, considered to be Drâa crossbreds were studied in Demnate and Ouarzazate in Tahnnaoutat the Center for Goat Research in the Marrakech area. Finally, 189 Rhâali goats from the Zagora region were also included. There is no herdbook information for any goat breed in Morocco.

The characteristics evaluated were wither and brisket height, thorax depth and ear length (all measured in $\mathrm{cm}$ ). Body morphometric measurements were taken using a tape measure on animals that were standing on the ground. Wither height (WH) was considered as the distance between the highest point of the wither to the front-leg distal extremity, brisket height (BH), as the distance from the brisket to the ground, ear length (EL), as the distance from ear base to end. Thorax depth (TD), was calculated from the difference between wither (WH) and brisket $(\mathrm{BH})$ heights, as direct measurement of TD is not easily accomplished in the field. Therefore, TD was calculated from the difference between two measures (WH-BH). Indices/relationships were also calculated between these measurements, such as TD/WH, EL/TD and EL/WH, for each individual. The absence of valid records for birth-dates required estimating 
age through dental chronology according to the methodology described by Quittet (1978).

Due to the use of variables measured in different units (linear measures as well as ratios between them), standardization of the variables $\left(Z_{i j}\right)$ was necessary. This standardized measurement: $Z_{i j}=\left(X_{i j}-\bar{X}_{j}\right) / S_{j}$, where $X_{i j}$ is the value of $i$-th observation of the variable $X_{j} ; \bar{X}_{j}$ is the mean of variable $X_{j}$ and $S_{j}$ is the standard deviation of variable $X_{j}$.

Before the collected physical measurements were subjected to analysis using multivariate methods, they were submitted to preliminary analyses to remove invalid data, particularly to discard information in compatible with stated age and to eliminate animals with missing information. Biometric data were first analyzed using simple descriptive statistics (mean, standard deviation and coefficient of variation). The coefficient of variation (CV) was calculated via the expression $\mathrm{CV}=\left(S_{j} / \bar{X}_{j}\right)^{*} 100$, where $S_{j}$ and were defined previously. Variables were then submitted to principal component analysis (PCA) to so reduce data dimensionality and enable discrimination of groups by individuals and populations.

The criterion for discarding variables from the PCA followed the recommendations of Jolliffe (1973), based on actual and simulated data from the correlation matrix. It was defined that the number of discarded variables should be the same as the components whose variance (eigenvalue) is not greater than 0.7 .

Multivariate analysis was with SAS version 8.0 software, under license to the Universidade Federal de Viçosa (SAS Institute Inc., Cary, NC, USA, 1999) and GENES version 6.0 software (Cruz, 2008).

\section{Results and Discussion}

The coefficients of variation of characteristics and indices showed these to be precisely estimated. The body morphometric measurements (WH, BH, EL and TD) presented coefficients of variation no greater than $12.8 \%$ (Table 1). The highest variability was in EL. In one group of goats, the Nambi-type, ears were substantially shorter,

Table 1 - Means, standard deviation and coefficient of variation of body measures and indices in Brazilian and Moroccan goats.

\begin{tabular}{lccc}
\hline Characters & Mean & $\begin{array}{c}\text { Standard } \\
\text { deviation }\end{array}$ & $\begin{array}{c}\text { Coefficient of } \\
\text { variation (\%) }\end{array}$ \\
\hline $\mathrm{WH}$ & $68.0 \mathrm{~cm}$ & $7.5 \mathrm{~cm}$ & 6.5 \\
$\mathrm{BH}$ & $36.6 \mathrm{~cm}$ & $4.8 \mathrm{~cm}$ & 9.1 \\
$\mathrm{EL}$ & $16.3 \mathrm{~cm}$ & $3.9 \mathrm{~cm}$ & 12.8 \\
$\mathrm{TD}$ & $31.4 \mathrm{~cm}$ & $5.3 \mathrm{~cm}$ & 10.3 \\
$\mathrm{TD} / \mathrm{WH}$ & 0.5 & 0.1 & 8.2 \\
$\mathrm{EL} / \mathrm{TD}$ & 0.5 & 0.2 & 18.2 \\
$\mathrm{EL} / \mathrm{WH}$ & 0.2 & 0.1 & 13.0 \\
\hline
\end{tabular}

WH - wither height, $\mathrm{pH}$ - brisket height, EL - ear length, PT - thoracic depth. whereas other groups characteristic ally had average-sized to long ears. The coefficient of variation values of $\mathrm{WH}, \mathrm{EL}$ and TD were similar to those found by Dossa et al. (2007).

Based on the PCA results, the respective eigenvalues, and the percentages of explained variance (Table 2) from the seven principal components, four of the components $(57.14 \%)$ yielded variances no greater than 0.7 (eigenvalues no greater than 0.7 ). The first three principal components were selected and explained $99.5 \%$ of the total variation.

As presented in Table 3, the four variables that presented the highest coefficients, in absolute value, from the last principal component can be discarded. Hence, the most appropriate characteristics to discard, in order of the least important for explaining total variation were TD, EL/WH TD/WH and EL/TD. Based on our results, wither height, brisket height and ear length are recommended for use in future studies. The indices and TD accounted for only $0.5 \%$ of the total variability. In this study, they were of little importance in the evaluation of interbreed differences. Notably, those characteristics recommended for exclusion were highly correlated with the selected variables. Based on the results, it is not recommended that thoracic depth be calcu-

Table 2 - Principal Components (PC), eigenvalues $\left(\lambda_{\mathrm{i}}\right)$ and variance percentage explained by components (simple variance and accumulated variance) of measured characteristics in Brazilian and Moroccan goats.

\begin{tabular}{lccc}
\hline Number & $\lambda_{\mathrm{i}}$ & Simple variance (\%) & Accumulated variance (\%) \\
\hline $\mathrm{PC}_{1}$ & 3.479 & 49.69 & 49.69 \\
$\mathrm{PC}_{2}$ & 1.971 & 28.15 & 77.84 \\
$\mathrm{PC}_{3}$ & 1.517 & 21.67 & 99.51 \\
$\mathrm{PC}_{4}$ & 0.025 & 0.36 & 99.87 \\
$\mathrm{PC}_{5}$ & 0.005 & 0.07 & 99.94 \\
$\mathrm{PC}_{6}$ & 0.003 & 0.05 & 99.99 \\
$\mathrm{PC}_{7}$ & 0.001 & 0.01 & 100.00 \\
\hline
\end{tabular}

Table 3 - Coefficients of weight of the variables with the four less important principal components to explain total variation.

\begin{tabular}{lcccc}
\hline Coefficients & \multicolumn{5}{l}{} \\
\hline Variable & $\mathrm{PC}_{4}$ & $\mathrm{PC}_{5}$ & $\mathrm{PC}_{6}$ & $\mathrm{PC}_{7}$ \\
\hline $\mathrm{WH}$ & 0.1410 & 0.0299 & -0.0929 & -0.6264 \\
$\mathrm{PH}$ & -0.1504 & 0.4627 & 0.1377 & 0.4606 \\
$\mathrm{EL}$ & -0.5216 & -0.3762 & 0.3704 & 0.0012 \\
$\mathrm{TD}$ & 0.3366 & -0.3752 & -0.2566 & $\mathbf{0 . 7 1 0 1}$ \\
$\mathrm{TD} / \mathrm{WH}$ & -0.0159 & $\mathbf{0 . 5 9 3 0}$ & 0.3966 & -0.0010 \\
$\mathrm{EL} / \mathrm{TD}$ & $\mathbf{0 . 7 5 3 8}$ & 0.0371 & 0.3693 & 0.0018 \\
$\mathrm{EL} / \mathrm{WH}$ & -0.0598 & 0.3868 & $\mathbf{- 0 . 6 8 9 7}$ & -0.0017 \\
\hline
\end{tabular}

WH - wither height, BH - brisket height, EL - ear length, TD - thoracic depth.

*The bold-face values are of the variable with the highest scores in the last four principal components. 
lated in future studies, but, instead, be substituted by brisket height. A population data set with additional animals and populations, and possibly much more diverse than that applied here, might have given rise to a different set of characteristics.

As can be seen in the graphical representation of the individual distribution according to principal components 1 and 2 (Figure 1), individuals from the European dairy breeds, Alpine, Saanen and Toggenburg, predominantly occupied the upper left quadrant. The relationships between these three breeds were corroborated by the grouping of the Saanen and Alpine, and the further grouping of the latter with the Toggenburg, as observed by electrophoresis of serum and erythrocyte proteins, and by microsatellite markers (Igarashi et al., 2000; Oliveira et al., 2007). The fact that our principal components data, based on physical measurements of these purebred animals of known pedigree origin, grouped these breeds together in the same way as did the protein and microsatellite markers, corroborates the use of biometric data and PCA for discerning differences among groups of individuals within a variety of populations.

The Moroccan goats were separated into two groups (Figure 1). Observations from the Drâa breed were located in the upper quadrants, mainly to the right, whereas those of the Zagora and Rhâali were located in the center of the lower quadrants. Some Drâa individuals were situated among the European dairy breeds. These results are partially in accordance with Machado et al. (2000), who, by comparing allelic frequencies of morphological characters, found that, where as the Zagora and Rhâali breeds were the closest grouped among the Moroccan types, the Drâa grouped together with Mediterranean-European goats. On the other hand, Ouali et al. (2002) report that in their phylogenic tree the Drâa-Zagora and Rhâali goats were very much separated from the Alpine and Saanen goats .Considering the data obtained from this experiment and those obtained by Machado et al. (2000), arbitrary pregrouping of Drâa and Zagora samples can be considered inadvisable.

Data from the Boer breed occupied the central area of the upper quadrants, especially that on the right, together with the Zagora, Drâa and Anglo-Nubian groups. The African component of the Boer and Anglo-Nubian breeds could possibly clarify this result. Thus, in this study, relationships among populations through PCA relate well with their respective breed descriptions and the geographical origins of these populations.

Although as a whole, the Anglo-Nubian and undefined breed goats from Piauí were predominantly in the upper right quadrant, some Anglo-Nubian individuals were placed among the European dairy breeds. On the other hand, although some undefined individuals from Piauí were grouped in the right lower quadrant together with the Zagora and Rhâali, they occupied more extreme positions than was the case with other populations. In contrast, Nambi-type goats occupied positions in the far-left portion of the lower left quadrant.

The Brazilian goat types, Marota and Azul, were also positioned in the lower left quadrant, in an intermediate position between the Nambi and Moroccan populations. However, in the case of the Azul goats, some individuals overlapped into the right-hand quadrant, thus denoting greater variability than the rest. In this case, the distribution of individuals through principal components 1 and 2 , which

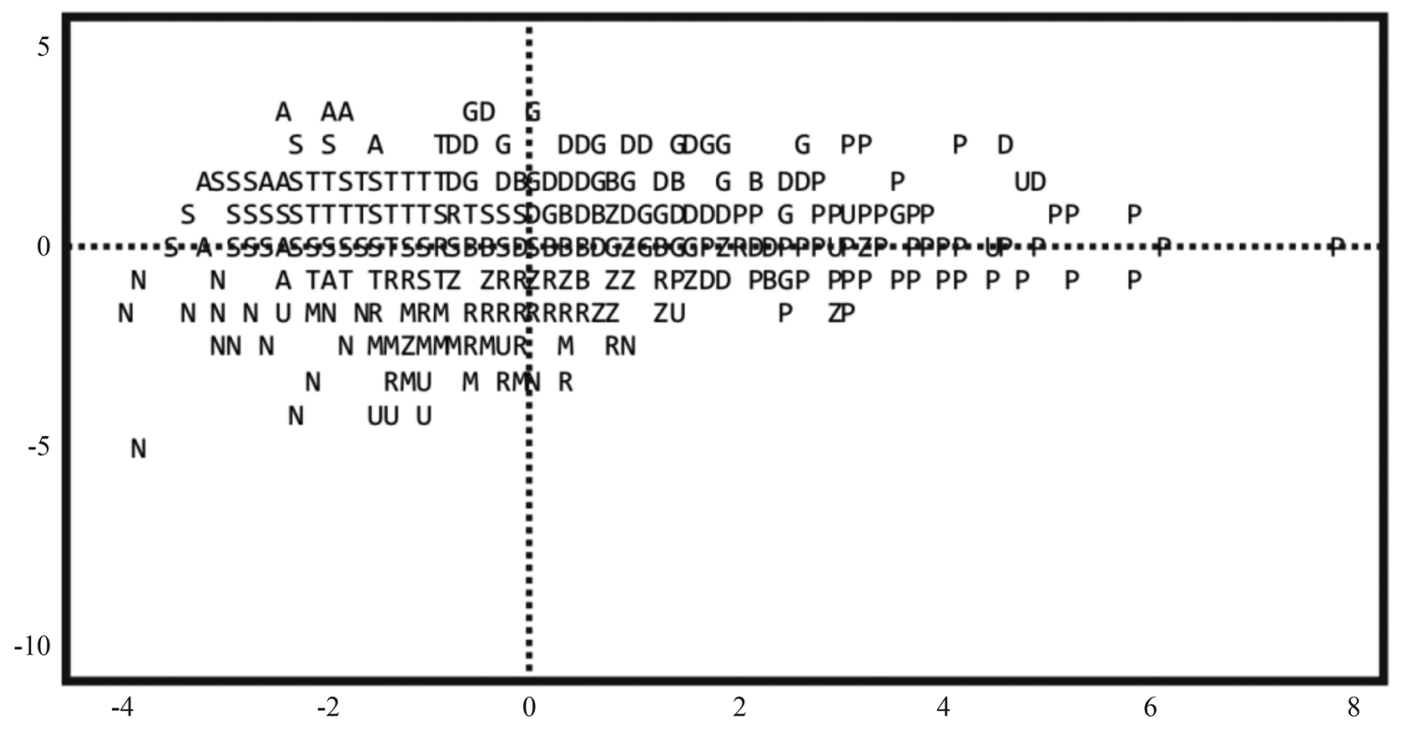

Figure 1 - Graphical dispersion of scores of 12 genetic groups of goats in Brazil and Morocco, related to principal components (PC) 1 (abscissa) and 2 (ordinate). Genetic groups: $\mathrm{T}=$ Toggenburg, $\mathrm{S}=$ Saanen, $\mathrm{G}=$ Anglo-Nubian, $\mathrm{A}=$ Alpine, $\mathrm{B}=\mathrm{Boer}, \mathrm{D}=$ Drâa, $\mathrm{Z}=$ Zagora, $\mathrm{R}=\mathrm{Rhâali}, \mathrm{U}=\mathrm{Azul}$, $\mathrm{M}=\mathrm{Marota}$, $\mathrm{N}=$ Nambi, $\mathrm{P}=$ Undefined Breed Goats from Piauí. 
retain greater variance, was useful for providing a visualization of intra-population and inter-population variability.

By relating principal components to known breed variability (Figures 2 and 3), the Brazilian Nambi-type appears to be removed from all the other groups, due to its short ears. The undefined breed goats from Piauí were also isolated from the other groups and placed in apposition opposite to the Nambi type goats. The closest groups to the undefined breed goats from Piauí were the Moroccan and the Brazilian Azul and Marota goats. The only difference between the groupings in Figures 2 and 3 is the positioning of the Drâa breed, which was included with the other Moroccan breeds and some Brazilian goats in the first analysis and then with the European breeds in the second analysis. This difference is easily explained by the variability among

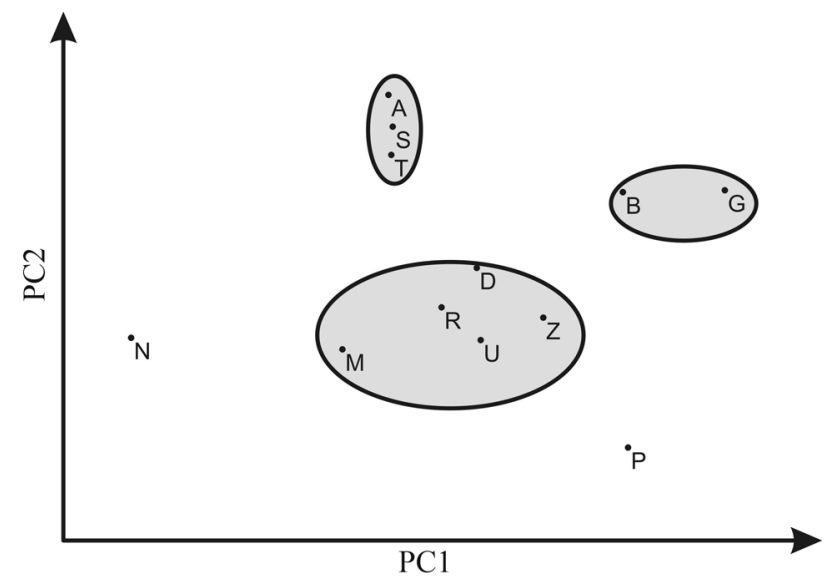

Figure 2 - Distribution of the 12 genetic groups of goats in Brazil and Morocco, in relation to the principal components 1 and 2.Genetic groups: $\mathrm{T}=$ Toggenburg, $\mathrm{S}=$ Saanen, $\mathrm{G}=$ Anglo-Nubian, $\mathrm{A}=$ Alpine, $\mathrm{B}=$ Boer, $\mathrm{D}=$ Drâa, $\mathrm{Z}=$ Zagora, $\mathrm{R}=$ Rhâali, $\mathrm{U}=$ Azul, $\mathrm{M}=$ Marota, $\mathrm{N}=$ Nambi, $\mathrm{P}=$ Undefined goat breeds from Piauí

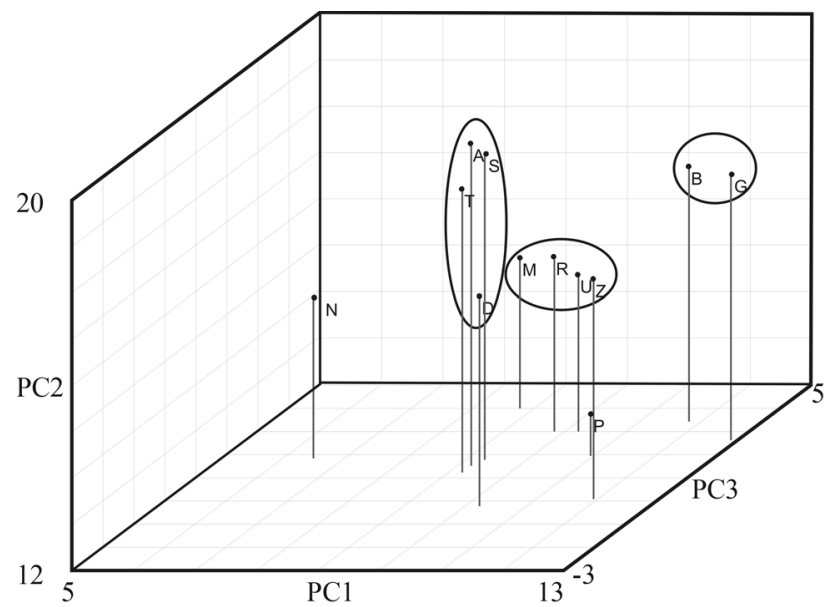

Figure 3 - Distribution of the 12 genetic groups of goats in Brazil and Morocco, in relation to the principal components 1,2 and 3.Genetic groups: $\mathrm{T}=$ Toggenburg, $\mathrm{S}=$ Saanen, $\mathrm{G}=$ Anglo-Nubian, $\mathrm{A}=$ Alpine, $\mathrm{B}=$ Boer, $\mathrm{D}=$ Drâa, $\mathrm{Z}=$ Zagora, $\mathrm{R}=$ Rhâali, $\mathrm{U}=$ Azul, $\mathrm{M}=$ Marota, $\mathrm{N}=$ Nambi, $\mathrm{P}=$ Undefined goat breeds from Piauí
Drâa individuals, as shown in Figure 1. In Figure 3, the group constituted by the Moroccan Rhâali plus Zagora and the Brazilian Azul and Marota goats occupied an intermediate position between the European dairy breeds together with the Drâa, and the Anglo-Nubian together with the Boer. These results are in accordance with the literature (Igarashi et al., 2000; Ouali et al., 2000; Oliveira et al., 2007), and occasionally also with the origins of the respective populations.

The graphical representation of PCA observations permits distinguishing among genetic groupings/breeds of goats, from the most similar to the most dissimilar. It also facilitates preliminary visualization of the uniformity or lack of uniformity among individuals within each population. Based on results from the Brazilian and Moroccan goat populations, the biometric indices, wither height, brisket height and ear length are recommended to be continued to be collected in future evaluations of breed and population diversity. In contrast, including thoracic depth is not recommended in further studies of this kind. Due to its greater variability, the Azul goat, an unselected type, demonstrated the least standardization of all the breeds. Among the Brazilian populations, the Nambi-type goats demonstrated the highest degree of uniformity, whence the trend to becoming a designated breed.

\section{Acknowledgments}

The authors would like to thank Mohamed Chakir for his contribution to data collection in Morocco during his post doctorate at INRA, Jouy-in-Josas, France.

\section{References}

Andrade MC (1982) Área de Domínio da Pecuária Extensiva e Semi-Intensiva na Bahia e Norte de Minas. SUDENE, Recife, 468 pp.

Audiot A (1985) La variant 'oreilles raccourcies' de la chèvre provençale. Recl Méd Vét 161:683-684.

Baker JF, Stewart TS, Long CR and Cartwright TC (1988) Multiple regression and principal components analysis of puberty and growth in cattle. J Anim Sci 66:2147-2158.

Bedotti D, Gómez Castro AG, Sánchez Rodriguez M and Martos Peinado J (2004) Morphologic and phaneroptic characterization of the pampean Red Goat. Arch Zootec 53:261-271.

Brasil (1977) Leis, Decretos, etc. Portaria $n^{\circ} 11$ de $1^{\circ}$ Dezembro de 1977. Padrões Raciais dos Caprinos. Diário Oficial, Brasília, pp 17187-17189.

Bouchel D, Lauvergne JJ, Guibert E and Minvielle F (1997) Étude morpho-biométrique de la chèvre du rove. Hauteur au garrot (HT), profondeur du thorax (PT), vide sous-sternal (VSS) et índice de gracilité sous-sternale (IGs) chez femelles. Rev Méd Vét 148:37-46.

Bourzat D, Souvenir-Zafindrajaona P, Lauvergne JJ and Zeuh V (1993) Comparaison morpho-biométrique dês chèves au Nord Cameroun et au Tchad. Rev d'Élevage et de Méd Vét des Pays Trop 46:667-674. 
Bruford MW, Bradeley DG and Luikart G (2003) DNA markers reveal the complexity of livestock domestication. Nat Rev Genet 4:900-910.

Chácon E, Macedo F, Velãzquez F, Paiva SR, Pineda E and McManus C (2011) Morphological measurements and body índices for Cuban Creole goats and their crossbreds. Rev Bras Zootec 40:1671-1679.

Cruz CD (2008) Programa Genes: Aplicativo Computacional em Genética ver. 6.0. Viçosa, Minas Gerais, 386 pp.

Dossa LH, Wollny C and Gauly M (2007) Spatial variation in goat populations from Benin as revealed by multivariate analysis of morphological traits. Small Rumin Res 73:150-159.

Epstein H (1971) The Origin of the Domestic Animals of Africa. 2nd edition. Africana Publishing Corporation, New York, $719 \mathrm{pp}$.

Erasmus JA (2000) Adaptation to various environments and resistance to disease of the improved Boer goat. Small Rumin Res 36:179-187.

Hall SJG and Bradley DG (1995) Conserving livestock breed diversity. Trends Ecol Evo 110:267-270.

Herrera M, Rodero E, Gutierrez MJ, Pefia F and Rodero JM (1996) Application of multifactorial discriminant analysis in the morphostructural differentiation of Andalusian caprine breeds. Small Rumin Res 22:39-47.

Hossaini-Hilari J and Benlamlih S (1995) La chèvre Marocaine.Capacités d'adaptation aux conditions arides. Animal GenetResour Inf 15:51-56.

Hossaini-Hilari J and Mouslish Y (2002) La chevre Drâa. Potentiel de production et caracteristiques d'adaptation aux contraintes de l'environnement aride. Animal Genet Resour Inf 32:49-56.

Igarashi MLSP, Machado TMM, Ferro JA and Contel EPB (2000) Structure and genetic relationship among naturalized and imported goat breeds. Biochem Genet 38:353-365.

Jolliffe IT (1973) Discarding variables in a principal component analysis. II. Real data. Appl Statist 22:21-31.

Jordana J, Ribo O and Pelegrin M (1993) Analysis of genetic relationships from morphological characters in Spanish goat breeds. Small Rumin Res 12:301-314.

Jordana J and Parés PM (1999) Relaciones genéticas entre razas ibéricas de caballos utilizando caracteres morfológicos (protótipos raciales). Agri 26:75-94.

Lauvergne JJ (1988) Populations Traditionnelles et Premières Races Standardisées d'Ovicaprinæ dans le Bassin Méditerranéen. INRA, Paris, pp 298.

Lauvergne JJ, Bourzat D and Minville F (2000) Using morphobiometric indices to map goat resources in Africa. In:
Blech RM and Macdonald KC (eds) The Origins and Development of African Livestock: Archaeology, Genetics, Linguistics and Ethnography. UCL Press, London and New York, pp 290-301.

Liberato JR, Vale FXR and Cruz CD (1999) Técnicas estatísticas de análise multivariada e a necessidade de o fitopatologista conhecê-las. Fitopatol Brasil 24:5-8.

Machado TMM, Chakir M and Lauvergne JJ (2000) Genetic distances and taxonomic trees between goats of Ceará state (Brazil) and goats of the Mediterranean region (Europe and Africa). Genet Mol Biol 23:121-125.

Malan SW (2000) The improved Boer goat. Small Rumin Res 36:165-170.

Mason IL (1988) A World Dictionary of Livestock Breeds, Types and Varieties. 3rd edition. CABI, Wallingford, $348 \mathrm{pp}$.

Meyer D (1996) Árvores Evolutivas Humanas: Uma Discussão sobre Inferência Filogenética. Sociedade Brasileira de Genética, Ribeirão Preto, 162 pp.

Oliveira JD, Igarashi MLSP, Machado TMM, Miretti MM, Ferro JA and Contel EPB (2007) Structure and genetic relationships between Brazilian naturalized and exotic purebred goat (Capra hircus) breeds based in microsatellites. Genet Mol Biol 30:356-363.

Ouali AT, Babilliot JM, Leroux C and Martin P (2002) Genetic diversity of the two main Moroccan goat breeds: Phylogenetic relationships with four breeds reared in France. Small Ru$\min$ Res 45:225-233.

Quittet E (1978) La cabra: Guia Practica para el Ganadero. Mundi-Prensa, Madrid, $321 \mathrm{pp}$.

Rocha LL, Benício RC, Oliveira JCV, Ribeiro MN and Delgado JV (2007) Estimation of morphoestructural traits in Moxoto breed goats. Arch Zootec 56:483-488.

Rodero Serrano E, Herrera García M and Gutiérrez Cabezas MJ (1992) Morphostructural evolution of the Blanca Serrana caprine breed based of their crossing for milking aptitude. Arch Zootec 41:519-530.

SAS/STAT (1999) User's Guide, ver. 8.0. SAS Institut Inc, Cary.

Sierra Alfranca I (2001) The breed concept: Evolution and reality. Arch Zootec 50:547-564.

Skinner JD (1972) Utilization of the Boer goat for intensive animal production. Trop Anim Health Prod 4:120-128.

Associate Editor: Bertram Brenig

License information: This is an open-access article distributed under the terms of the Creative Commons Attribution License, which permits unrestricted use, distribution, and reproduction in any medium, provided the original work is properly cited. 